\title{
Instrumental Neutron Activation Analysis of Total Halogen and Extractable Organohalogen in Fish Samples from the Densu Basin
}

\author{
Alfred Kwablah Anim (Corresponding author) \\ National Nuclear Research Institute,Ghana Atomic Energy Commission \\ P. O. Box LG. 80, Legon, Accra, Ghana \\ Tel: 233-208-533-816 E-mail: sekemont@yahoo.com
}

Samuel Afful

National Nuclear Research Institute,Ghana Atomic Energy Commission

P. O. Box LG. 80, Legon, Accra, Ghana

Tel: 233-275-809-933 E-mail: samuelaffu@yahoo.com

Yaw Serfor-Armah

National Nuclear Research Institute,Ghana Atomic Energy Commission

P. O. Box LG. 80, Legon, Accra

\&

Department of Nuclear Sciences and Applications, Graduate School of Nuclear and Allied Sciences

University of Ghana, P. O. Box AE1, Atomic Campus, Accra, Ghana

Tel: 233-543-426-365Ｅ-mail: yawserfor@yahoo.com

\begin{abstract}
Instrumental Neutron Activation Analysis (INAA) has been validated and the method applied to determine total halogen and extractable organohalogen in six fish species namely Heterotis niloticus, Channa obscura, Hepsetus odoe, Tilapia zilli, Clarias gariepinus, and Chrysichthys nigrodigitatus. The samples were collected directly from the fishermen at their landing sites from the two sampling towns, Weija and Nsawam along the Densu river basin in the Greater Accra Region of Ghana. The concentrations of total chlorine, bromine, and iodine analysed by INAA were between $770.70-1123.50 \mathrm{mg} / \mathrm{kg}, 8.00-25.00 \mathrm{mg} / \mathrm{kg}$ and $0.70-4.20 \mathrm{mg} / \mathrm{kg}$ respectively. For the extractable organohalogens concentrations ranged from $0.30-350.40 \mathrm{mg} / \mathrm{kg}$. The highest concentration of 350.40 $\mathrm{mg} / \mathrm{kg}$ was obtained for extractable organochlorine (EOCl) in Hepsetus odoe sampled from Nsawam, while the lowest concentration was obtained for extractable organoiodine. The content of extractable organohalogen were in the order of $\mathrm{EOCl}>>\mathrm{EOBr}>\mathrm{EOI}$.
\end{abstract}

Keywords: Neutron activation, Organohalogen, Fish species, Densu basin, Extractable

\section{Introducton}

Environmental chemists, for the past few years, have increased their efforts for the detection of chemicals which are polluting the environment. However, in spite of these efforts, only a limited proportion of the chemicals in the environment have been detected and listed as pollutants. Organohalogens are environmental pollutants, considered as one of the most toxic pollutants of concern. This is because of their persistence in the environment, biota and their adverse effects on organisms [Kawano M, 2004]. Organohalogens have been implicated in a broad range of adverse human health effects including reproductive failures and birth defects, immune system malfunction, endocrine disruptions, and cancers [Garabrant D. H, 1992, p764-771]. Organohalogens, especially organochlorine compounds (OCs), have long been recognized as a potential threat to human health and, therefore these compounds have been widely investigated in foods, vegetation and the atmosphere [Diandu X, 2004, p101-106]. Infants and children are particularly prone to absorbing brominated flame retardants (BFRs) and chlorinated flame retardants (CFRs) through direct physical or oral contact with these compounds in furniture, inhalation of furniture dust containing BFRs and CFRs, and via ingestion of these substances from their mother's milk and from their 
diets [Wu ming, 2007]. Common uses of organohalogens include solvents, pesticides, flame retardants, refrigerants, and ingredients of elastomers, adhesives, electrical insulating coatings, plasticizers, and plastics. It is therefore obvious that they are widely used by man.

As a result of the toxicity associated with organohalogens, determination of levels of organohalogens in the environment, particularly in food and water samples are becoming increasingly important. Interest in using extractable organohalogens (EOX) as parameters for the quantification of total organohalogen content in sediment [Gustavson K, 1999, p723-736], biota [ Haynes D, 1995, p 463-469], and water [Martinsen K, 1988, p13-24] has dramatically increased. Instrumental neutron activation (INAA) has become one of the most important and most suitable techniques for the determination of organohalogen compounds in environmental samples due to its capability to analyze individual halogens. It is a very reliable analytical tool for simultaneously determining extractable organochlorine $(\mathrm{EOCl})$, extractable organobromine $(\mathrm{EOBr})$, and extractable organoiodine (EOI) [Lunde G, 1976, p180-183]. Recently, INAA was conducted for the analysis of EOX in the blubber samples of harbor porpoise and whole body samples of Atlantic herring from the Baltic sea [Kawano M, 2008, p263-266]. Diando Xu et al (2004) analyzed pine needles and foodstuffs collected from Beijing, China, by instrumental neutron activation analysis (INAA) combined with organic solvent extraction for total halogens, extractable organohalogens (EOX) and extractable persistent organohalogen (EPOX).

In this study, INAA has been validated using three reference standard materials, and the validated method has been applied for the determination of total organohalogens and extractable organohalogens (EOX) in fish species sampled from the Densu basin. The Densu basin was selected, to help in establishing the level of organohalogen contamination in the basin and the matrix fish was used for the study as fish can readily accumulate organohalogens through inhalation, dermal absorption and ingestion and therefore, can serve as a biomonitor to indicate the levels of environmental contamination of organohalogen compounds.

\section{Materials and methods}

\subsection{Study area}

The Densu River system is one of the coastal drainage basins of Ghana. The river lies between latitudes $5^{\circ} 30^{\prime} \mathrm{N}$ to $6^{\circ} 20^{\prime} \mathrm{N}$ and longitudes $0^{\circ} 10^{\prime} \mathrm{W}$ to $0^{\circ} 35^{\prime} \mathrm{W}$. The basin area is about $2488.41 \mathrm{~km}^{2}$ with an average length of $225.6 \mathrm{~km}$ [ Akpabli CK, 2001, p85-86]. Its main tributaries are the Kuia, Adaiso, Nsaki and Aprapon. The basin plays a critical role in the socio-economic development of the many towns and satellite villages dotted within it. Other small settlements also depend on untreated water from the Densu River and its tributaries. The Densu Basin is also intensively used for the cultivation of both cash and food crops. Principal food crops cultivated within the basin are cassava, maize, yam, plantain, banana and cocoyam. Cash crops include cocoa, oil palm, papaya, pineapple, mangoes and citrus. Farmers here use fertilizers and other agrochemicals extensively. Sulphate, phosphate, nitrate and chloride based fertilisers and other agrochemicals, including calcium cabide and kerosene, are used in the farms, which are washed into the river through run-off. In the Adaiso township, car washing, an important economic activity can be identified along the river. Other land use activities include housing, sand winning, animal rearing, salt mining etc. Another economic activity in the Densu basin is fishing. Most of the towns and villages including city dwellers in Accra get their fish supply from the Densu basin. Commercial fishing sites in the basin include Nsawam and Weija. Major large scale commercial pineapple farms, such as, Oyoko farms (New Doblo), Greenlex Farms Ltd. (Dobro), John Laurence Farm Limited is located along the course of river Densu. The Densu finally flows southwards into the Weija reservoir and enters the Gulf of Guinea through the Sakumono Lagoon at Botiano, a fishing village about 16km of west Accra. Fig.1 shows a map of the sampling area.

\subsection{Sample Collection}

Six fish species were collected from Weija and Nsawam portions of the Densu basin for the study. Fish samples were bought directly from commercial fishermen at the landing sites at Weija and Nsawam. The fish samples were packed in ice thermo insulator box and transported to the laboratory. At the laboratory, the fish samples were washed several times with deionized water. The fish species used for the investigation were: Tilapia Zilli, Chrysichthys Nigrodigitatus, Heterotis Niloticus, Channa Obscura, Hepsetus Odoe and Clarias Gariepinus. The fish samples were identified and unique identification codes were given.

\subsection{Sample preparation}

\subsubsection{Preparation of powdered fish samples}

Fish samples were removed from the freezer and rinsed several times with deionised water. Prior to preparation, each sample was weighed and its lengths were measured. Each fish sample was gutted to remove the intestines. 
The scales, head, tails, fins and bones were also removed using a stainless steel knife. One pooled (composite) sample was prepared for each different species from five individual fish species. The muscle tissues of the five individual fish were ground in a waring stainless steel blender to obtain a homogenous fish sample. $100 \mathrm{~g}$ of each homogenized sample were freeze dried for $72 \mathrm{hrs}$. The dried samples were ground using mortar and pestle to obtain powdered sample.

\subsubsection{Soxhlet extraction}

A mass of $10 \mathrm{~g}$ of dried powdered fish samples were weighed and wrapped in a filter paper. The wrapped fish samples were placed in a cellulose extraction thimble and extracted with $160 \mathrm{ml}$ of hexane: acetone mixture in the ratio 3:1 for five hours using soxhlet extraction procedure. The extracts were concentrated to dryness on a rotary evaporator fitted to a vacuum pump in a fume chamber. The extracts were recovered by re-dissolving the residues in $10 \mathrm{ml}$ of hexane. A sample blank was also prepared.

\subsubsection{Preparation of samples for irradiation}

$200 \mathrm{mg}$ of dried homogenized sample were weighed onto clean polyethylene sheets, wrapped and heat sealed. The sealed samples were then packed into $7 \mathrm{ml}$ polyethylene vials and the vials were heat sealed for irradiation for determination of total $\mathrm{Cl}, \mathrm{Br}$ and I content by INAA. Three reference materials namely NIST-SRM 1566b (Oyster tissue), CRM-DORM-2 (Dogfish muscle) and NIST-SRM 1547 (Peach leaves) were prepared and packaged in a similar manner. To determine the extractable organohalogen, $200 \mathrm{mg}$ of the concentrated extract were weighed into $1.5 \mathrm{ml}$ polyethylene vial, plugged with cotton wool and heat sealed. The $1.5 \mathrm{ml}$ vials were then packed into a 7 $\mathrm{ml}$ polyethylene vial, plugged with cotton wool and heat sealed for irradiation to determine the concentration of $\mathrm{EOCl}, \mathrm{EOBr}$ and $\mathrm{EOI}$ in the fish samples.

\subsubsection{Preparation of elemental comparator standards for analysis of EOX}

The potassium halide salts were dried in an oven for at least $24 \mathrm{~h}$ at $110^{\circ} \mathrm{C}$, then transferred to and stored in a desiccator. These salts were used to produce the aqueous comparator standards used for the study. Standard solutions were made for each of the halogens studied, i.e. chlorine, bromine and iodine. The final standard solution for irradiation contained the following concentrations: $10.0 \mathrm{ppm}$ chlorine, $0.439 \mathrm{ppm}$ bromine, and $0.227 \mathrm{ppm}$ iodine. Vials containing these aqueous standards were prepared as per section 2.3.3.

\subsubsection{Instrumental neutron activation analysis (INAA) of fish samples}

INAA was validated to analyse total $\mathrm{Cl}, \mathrm{Br}, \mathrm{I}$, and $\mathrm{EOCl}, \mathrm{EOBr}, \mathrm{EOI}$ in the fish samples. Irradiations were performed using the Ghana Research Reactor-1 (GHARR-1) of Ghana Atomic Energy Commission at Kwabenya. The samples, comparator standards and reference materials were all irradiated using thermal irradiation. The reference materials were: NIST-SRM 1566b (Oyster tissue), CRM-DORM-2 (Dogfish muscle) and NIST-SRM 1547 (Peach leaves). GHARR-1 is a 30KW tank-in-pool reactor using light water as moderator and coolant. The fuel source is highly enriched Uranium $(90.2 \%$-Al alloy) with metal beryllium as reflectors. The reactor is cooled by natural convection. Samples were sent to the irradiation sites by means of a pneumatic transfer system. The samples were irradiated with a thermal flux of $5 \times 10^{11} \mathrm{ncm}^{-2} \mathrm{~s}^{-1}$ with the reactor operating at $15 \mathrm{KW}$. The elements of interest were assayed using different timing parameters. $\mathrm{Cl}$, EOCl, I and $\mathrm{EOI}$ were typically determined in the samples after $2 \mathrm{~min}$ irradiation, 1-10 min decay and 10 min counting period (ti: $\mathrm{td}: \mathrm{tc}=2: 1-10: 10 \mathrm{~min}$ ). For $\mathrm{Br}$ and EOBr the samples were irradiated for $1 \mathrm{hr}$ and allowed to decay for $24 \mathrm{hrs}$ and counted for $10 \mathrm{~min}$. Nuclear data [ IAEA-TECDOC-564, 1990] for these nuclides are provided in Table 1.

\subsubsection{Counting of irradiated samples}

The irradiated samples were counted by using a computer based gamma-ray spectroscopy system, consisting of an N-type high purity Germanium (HPGe) detector model GR2518 mounted on liquid nitrogen as a coolant, high voltage power supply model 3103, Spectroscopy amplifier model 2020, ACCUSPEC multi-channel analyzer emulation software card (all manufactured by Canberra industries inc.), and a micro computer for data acquisition, evaluation and analysis. The qualitative and quantitative analyses of the nuclides were achieved using the MAESTRO 32 software. The quantitative analysis was done by converting the counts as area under the photo peak of the radionuclide by the comparator method

\section{Results and discussion}

\subsection{Validation of NAA method}

Results obtained when the INAA method was validated using three reference standard materials are presented in Tables 2,3, and 4 . The elemental levels obtained for the standard reference in the present study are compared with reported values. The two sets of data agree favorably within the limits of experimental error, suggesting the 
accuracy and reliability of elemental measurement by non-destructive INAA. The results of the present study were in most cases within $0.5-5 \%$ deviation of reported values.

\subsection{Total and extractable organohalogens}

The mean concentrations of total halogens and extractable organohalogens (EOX) are presented in Table 5 . Margins of errors are standard deviation based on triplicate determination. Results show higher levels of total chlorine and lower levels of total iodine in all the samples. The total halogen content in all the samples were of the order total $\mathrm{Cl}>$ total $\mathrm{Br}>$ total I. Over all, the highest concentration, $1123.50 \pm 29.10 \mathrm{mg} / \mathrm{kg}$ in Channa obscura $(\mathrm{CON})$ was obtained for total $\mathrm{Cl}$ while the lowest concentration, $0.70 \pm 0.01 \mathrm{mg} / \mathrm{kg}$ was obtained for total I in Heterotis niloticus (HNN).

Results show the presence of extractable organohalogen (EOX) in all the samples. The levels of EOX also followed the same trend as levels of total halogen. Thus the highest extractable organohalogen was extractable organochlorine with a mean concentration of $350.40 \pm 9.10 \mathrm{mg} / \mathrm{kg}$ extracted from Hepsetus odoe (HON), while the lowest extractable organohalogen was organoiodine with mean concentration of $0.30 \pm 0.01 \mathrm{mg} / \mathrm{kg}$ extracted from Channa obscura (CON). The reasons for the high content of EOCl may be attributed to the nature of organochlorines being more difficult to be transformed and degraded compared to brominated and iodinated compounds in the environment [Laniewski K, 1999, p 393-409]. Another likely factor is the huge amount of organochlorinated compounds which are continuously being released into the environment through the extensive use of organochlorinated agrochemicals for agriculture purposes. It is also known that most organohalogenated pollutants in the atmosphere are present as organochlorines and these can deposit in river bodies when it rains. Laniewski et al had established that most absorbable organohalogens in rain and snow were organochlorines. Further evidence provided suggests that chlorinated methane which originates from both natural and anthropogenic sources was the most abundant organohalogen in the atmosphere[Yokouchi Y, 2000, p295-298].

The high concentrations of the extractable organochlorines were however not comparable to the respective concentrations of the total chlorine. On the other hand, the concentrations of extractable bromine and iodine were comparable to their corresponding total bromine and total iodine. For instance, the total chlorine content in CGW was $951.60 \pm 36.30 \mathrm{mg} / \mathrm{kg}$, while the corresponding extractable organochlorine was $216.00 \pm 8.90 \mathrm{mg} / \mathrm{kg}$. For the same sample, the total bromine and total iodine content were $10.70 \pm 0.20$ and $1.40 \pm 0.02 \mathrm{mg} / \mathrm{kg}$ respectively and their corresponding extractable bromine and iodine were respectively $8.20 \pm 0.10$ and $1.35 \pm 0.02$ $\mathrm{mg} / \mathrm{kg}$. This results show that most of the total chlorine in the samples are likely to be inorganic as much was not extractable. However, the content of total bromine and total iodine in the samples are predominantly organic in nature as greater percentage was extractable. Thus, as presented in Fig 2, in terms of percentage compositions of extractable organohalogens in relation to their corresponding total halogen, percentage extractable organochlorine was the lowest. It must however, be noted that the content of extractable organohalogen were in the order of $\mathrm{EOCl}>>\mathrm{EOBr}>\mathrm{EOI}$. The same order of the concentration for EOX in harbor porpoise and whole body samples of Atlantic herring from the Baltic sea were reported [Kawano M, 2008, p263-266]. Heterotis niloticus (HNN) however recorded exceptionally high EOBr mean concentration of $13.00 \mathrm{mg} / \mathrm{kg}$. This sharp difference may be due to differences in the characteristics of Heterotis niloticus which consume small invertebrates, phytoplankton seeds and also eats more frequently over a long period.

Fig. 3 compares the distribution of $\mathrm{EOCl}$ in the fish samples from various sample points. The concentrations of EOCl range between 327.50 to $150.00 \mathrm{mg} / \mathrm{kg}$. Lower concentrations between 17.7 and $43.35 \mathrm{mg} / \mathrm{kg}$ of EOCl were reported in freshwater mussel tissues [Kawano M, 2001, p233-242]. Results show general higher concentrations of $\mathrm{EOCl}$ in samples from Nsawam and lower concentrations in samples from Weija. The level of organohalogens in biota can be contributed by both natural and artificial sources [Gribble G.W, 2003, p289-297]. Nsawam is located upstream where there is a lot of farming activities whilst Weija which is located downstream experiences less agricultural activities. Considering the description of the sampling sites, samples from Nsawam are likely to be more exposed to pesticide residues from agricultural run-off compared to samples from Weija.

Unlike the distribution of EOCl [Fig. 3], levels of EOBr and EOI were however higher in samples from Weija compared to samples from Nsawam [Fig. 4]. Weija is located closer to the sea and also exposed more to automobile emissions due to its closeness to the motor traffic hub. This may contaminate the Weija site with $\mathrm{Br}$ from likely emissions of $\mathrm{Br}$ containing compounds from vehicle exhaust fumes. Leachate from landfills and direct domestic waste disposal into the Densu basin may also be some of the $\mathrm{EOBr}$ contamination pathways into the Densu river basin. The Weija site is closer to the Oblogo landfill site and may therefore be the source of high levels of EOBr compared to levels in Nsawam. Another likely source of bromine contamination is the incineration processes which may release brominated flame retardants (BFRs) from furniture, mattresses. Brominated dioxins 
and furans may originate under conditions of incineration [De Wit C.A., 2002, p583-624]. Heterotis niloticus $(\mathrm{HNN})$ however recorded exceptionally high EOBr mean concentration of $13.00 \mathrm{mg} / \mathrm{kg}$. This sharp difference may be due to differences in the feeding characteristics of Heterotis niloticus.

High levels of EOI were obtained for samples from Weija compared to samples from Nsawam. The levels of iodine in aquatic organisms depend on the aquatic resource and the specie [Larsen E.H., 1997, p435-439].The sea is the major source of iodine. Thus much of the iodine in the basin may be contributed by deposition (spray) and intrusion from the sea. Weija is closer to the sea than Nsawam.

\section{Conclusion}

The results of this work indicated that organohalogens are present in the Densu basin. The incidence of EOCl, $\mathrm{EOBr}$ and $\mathrm{EOI}$ were $100 \%$. The percentage $\mathrm{EOCl}$ of the total chlorine in the fish samples ranged from 13.3 to $42.5 \%$. This is an indication that the chlorine content in the fish samples are more of inorganic origin. The EOBr and EOI accounted for $46.0-95.6 \%$ and $51.8-96.4 \%$ of the total bromine and iodine respectively in the fish samples. This result suggests that the bromine and iodine content in the Densu basin are more of organic origin and highly extractable. Notwithstanding the high percentage of EOBr and EOI relative to their corresponding total halogen, the levels of EOX in the fish samples were in the order of EOCl $>>\mathrm{EOBr}>\mathrm{EOI}$. The low levels of EOBr compared to EOCl suggests atmospheric deposition and leachate from other bromine containing compounds rather than brominated agrochemicals as the major contamination pathways. The higher levels of EOBr in samples from Weija compared to Nsawam therefore suggest the leaching of organobromines from the Oblogo landfill site which is sited in Weija and the atmospheric deposition of brominated flame retardants (BFR) which may be released during incineration of waste. The levels of EOI in the fish samples were exceptionally low. This may be attributed to the fact that organoiodines are easily transformed and degraded in the environment particularly in the tropics. The INAA methodology presented is efficient and reliable and can be used for routine determination of total and extractable organohalogens in environmental samples.

\section{References}

Akpabli C K, Drah G K. (2001). Water Quality of The Main Tributaries of the Densu River. J. of the Ghana Sci.Asso., 3 (2): 85-86.

De Wit C A. (2002). An overview of brominated flame retardants in the environment. Chemosphere, 46: 583-624.

Diandou X, Zhifang C, Hong Z, Xue ying M, Hong O. (2004). Study of Organohalogens in foodstuffs and environmental samples by neutron activation analysis and related techniques, Nucleonika, 49(3):101-106.

Garabrant D. H., J Held., B Langholz., J.M Peter, T.M Mark. (1992). DDT and Related Compounds and Risk of Pancreatic Cancer. J. Natl. Cancer Inst., 84 (10):764-771.

Gribble G.W. (2003). The Diversity Of Naturally Occuring Organohalogen Compounds. Chemosphere, 52:289-297.

Gustavson K, Jonsson P. (1999). Some halogenated organic compounds in sediments and blue mussel (Mytilus edulis) in Nordic Seas. Mar Pollut Bull, 38:723-736.

Haynes D, Mosse P, Levay G. (1995). The use of transplanted cultured mussels (Mytilus edulis) to monitor pollutants along the Ninety Mile Beach, Victoria, Australia. Mar Pollut Bull, 30:463-469.

IAEA-TECDOC-564. (1990). Practical aspects of operating NAA laboratory.Vienna. p.197-237.

Kawano M. (2004). Persistent organohalogens in environmental materials. Analytical Applications of Nuclear Techniques, IAEA.

Kawano M, Falandysz J, Morita M. (2008). Instrumental neutron activation analysis of extractable organohalogens in marine mammal, harbor porpoise (phocoena phocoena) and its feed, Atlantic herring (clupea harengus), from the Baltic sea. J. of Radioanalytical and Nuclear Chemistry, 278(2):263-266.

Kawano M, Sajwan K.S, Owen D.A. (2001). Extractable organohalogens (EOX) in sediment and mussel tissues from the Kentucky lake and Kentucky Dam tailwater, USA. Tox. And Environ. Chem., 79(3):233-242.

Laniewski K, Boren H, Grimwall A. (1999). Fraction of Halogenated Organic Matter Present in rain and Snow. Chemosphere, 38: 393-409.

Larsen E. H., M. B. Ludwigsen. (1997). Determination of Iodine in food related certified reference materials using wet ashing and detection by inductively coupled plasma mass spectrometry. J. Anal. Atomic Spectrometry, 12(1) :435-439. 
Lunde G, J Gether. (1976). Determination of volatility and chemical persistence of lipid-soluble halogenated organic substances in marine organisms. AMBIO, 5:180-183.

Martinsen K, Kringstad A, Carlberg G E. (1988). Methods for determination of some parameters and characterization of organochlorine compounds in spent bleach liquors from pulp mills and water, sediment and biological samples from receiving waters. Water Sci Technol, 20:13-24.

Wu ming. (2007). Californians for fire safety: chemical companies get cute with voters. [Online] Available: www.unbossed.com, accessed, $20^{\text {th }}$ Sept., 2008.

Yokouchi Y, Noijiri Y, Barrie L A. (2000). A Strong Source of Methyl Chloride to the atmosphere from tropical coastal land. Nature, 403: 295-298.

Table 1. Nuclear data for the elements

\begin{tabular}{ccccccccc}
\hline $\begin{array}{c}\text { Elements } \\
(\mathrm{Kev})\end{array}$ & $\begin{array}{c}\text { Isotope } \\
(\% \text { abund })\end{array}$ & Nuclide & $\begin{array}{c}\text { Cross-section } \\
(\mathrm{b})\end{array}$ & $\mathrm{T}_{1 / 2}$ & $\mathrm{t}_{\mathrm{i}}$ & $\mathrm{t}_{\mathrm{d}}$ & $\mathrm{t}_{\mathrm{c}}$ & Energy \\
\hline $\mathrm{Cl}$ & ${ }^{37} \mathrm{Cl}(24.23)$ & ${ }^{38} \mathrm{Cl}$ & $0.428 \pm 0.005$ & $37 \mathrm{~min}$ & $2 \mathrm{~min}$ & $1-10 \mathrm{~min}$ & $10 \mathrm{~min}$ & 1642.4 \\
& & & & & & & & 2167.5 \\
$\mathrm{Br}$ & ${ }^{81} \mathrm{Br}(49.31)$ & ${ }^{82} \mathrm{Br}$ & $2.69 \pm 0.09$ & $35.2 \mathrm{hrs}$ & $1 \mathrm{hr}$ & $24 \mathrm{hrs}$ & $10 \mathrm{~min}$ & 554.3 \\
& & & & & & & & 776.5 \\
$\mathrm{I}$ & ${ }^{127} \mathrm{I}(100.00)$ & ${ }^{128} \mathrm{I}$ & $6.2 \pm 0.2$ & $24.99 \mathrm{~min}$ & $2 \mathrm{~min}$ & $1-10 \mathrm{~min}$ & $10 \mathrm{~min}$ & 442.3 \\
\hline
\end{tabular}

Table 2. Comparison of elemental concentrations of NIST-SRM $1566^{\mathrm{b}}$ (Oyster tissue), reported values and local laboratory values $(\mathrm{mg} / \mathrm{kg})$

\begin{tabular}{ccc}
\hline Element & Present study & Reported value \\
\hline $\mathrm{Al}$ & $196.4 \pm 7.1$ & $197.2 \pm 6.0$ \\
$\mathrm{Ca}$ & $0.0796 \pm 0.0040$ & $0.0838 \pm 0.0020$ \\
$\mathrm{Cl}$ & $0.492 \pm 0.03$ & $0.514 \pm 0.01$ \\
$\mathrm{Co}$ & $0.331 \pm 0.021$ & $0.371 \pm 0.009$ \\
$\mathrm{Cu}$ & $69.04 \pm 2.0$ & $71.6 \pm 1.6$ \\
$\mathrm{~K}$ & $0.549 \pm 0.011$ & $0.652 \pm 0.009$ \\
$\mathrm{Mg}$ & $0.1990 \pm 0.0120$ & $0.1085 \pm 0.0023$ \\
$\mathrm{Mn}$ & $18.01 \pm 0.4$ & $18.5 \pm 0.2$ \\
\hline
\end{tabular}

Table 3. Comparison of elemental concentrations of CRM-DORM-2 (Dogfish muscle), reported values and local laboratory values $(\mathrm{mg} / \mathrm{kg})$

\begin{tabular}{lll}
\hline Element & Present work & Reported value \\
\hline $\mathrm{Al}$ & $10.41 \pm 1.2$ & $10.9 \pm 1.7$ \\
$\mathrm{As}$ & $19 \pm 0.9$ & $18 \pm 1.1$ \\
$\mathrm{Cd}$ & $0.051 \pm 0.006$ & $0.043 \pm 0.008$ \\
$\mathrm{Co}$ & $0.212 \pm 0.011$ & $0.182 \pm 0.031$ \\
$\mathrm{Cr}$ & $35.1 \pm 4.8$ & $34.7 \pm 5.5$ \\
$\mathrm{Cu}$ & $2.22 \pm 0.21$ & $2.34 \pm 0.16$ \\
$\mathrm{Fe}$ & $143 \pm 8$ & $142 \pm$ \\
$\mathrm{Ni}$ & $19.7 \pm 2.8$ & $19.4 \pm 3.1$ \\
$\mathrm{Zn}$ & $24.8 \pm 1.9$ & $25.6 \pm 2.3$ \\
\hline
\end{tabular}


Table 4. Comparison of elemental concentrations of NIST-SRM 1547 (Peach leaves), reported values and local laboratory values $(\mathrm{mg} / \mathrm{kg})$

\begin{tabular}{lll}
\hline Element & Present study & Reported value \\
\hline $\mathrm{Al}$ & $242 \pm 4.7$ & $249 \pm 8$ \\
$\mathrm{Br}$ & $12 \pm 0.28$ & $(11)^{*}$ \\
$\mathrm{Ca}(\%)$ & $1.60 \pm 0.06$ & $1.56 \pm 0.02$ \\
$\mathrm{Cl}$ & $358 \pm 16$ & $360 \pm 19$ \\
$\mathrm{Cu}$ & $3.9 \pm 0.3$ & $3.7 \pm 0.4$ \\
$\mathrm{I}$ & $0.4 \pm 0.02$ & $(0.3)^{*}$ \\
$\mathrm{~K}(\%)$ & $2.51 \pm 0.02$ & $2.43 \pm 0.03$ \\
$\mathrm{Mg}(\%)$ & $0.419 \pm 0.004$ & $0.432 \pm 0.008$ \\
$\mathrm{Na}$ & $22 \pm 0.18$ & $24 \pm 0.20$ \\
$\mathrm{Zn}$ & $17.2 \pm 0.3$ & $17.9 \pm 0.4$ \\
\hline
\end{tabular}

*Non Certified/Recommended value

Table 5. Mean concentration of total and extractable organohalogens (EOX) in the fish samples ( $\mathrm{mg} / \mathrm{kg}$ )

\begin{tabular}{ccccccc}
\hline Sample & Cl(Total) & EOCl & Br(Total) & EOBr & I(Total) & EOI \\
\hline & & & & & & \\
CGW & $951.60 \pm 36.30$ & $216.00 \pm 8.90$ & $10.70 \pm 0.20$ & $8.20 \pm 0.10$ & $1.40 \pm 0.02$ & $1.35 \pm 0.02$ \\
CNW & $1066.91 \pm 32.60$ & $227.50 \pm 6.80$ & $12.30 \pm 0.30$ & $8.40 \pm 0.10$ & $4.20 \pm 0.20$ & $1.70 \pm 0.03$ \\
TZW & $877.60 \pm 34.90$ & $189.10 \pm 4.00$ & $14.60 \pm 0.40$ & $11.00 \pm 0.10$ & $1.20 \pm 0.03$ & $0.70 \pm 0.01$ \\
HNN & $770.70 \pm 29.00$ & $327.50 \pm 14.50$ & $25.00 \pm 0.40$ & $13.00 \pm 0.10$ & $0.70 \pm 0.01$ & $0.50 \pm 0.01$ \\
CON & $1123.50 \pm 29.10$ & $150.00 \pm 5.20$ & $7.80 \pm 0.20$ & $7.40 \pm 0.10$ & $1.00 \pm 0.02$ & $0.30 \pm 0.01$ \\
HON & $831.10 \pm 25.20$ & $350.40 \pm 9.10$ & $10.30 \pm 0.30$ & $8.00 \pm 0.10$ & $1.50 \pm 0.03$ & $0.90 \pm 0.01$ \\
TZN & $931.00 \pm 27.60$ & $303.20 \pm 5.50$ & $14.60 \pm 0.20$ & $6.70 \pm 0.10$ & $0.80 \pm 0.02$ & $0.60 \pm 0.01$ \\
CGN & $846.50 \pm 29.70$ & $221.60 \pm 6.90$ & $8.50 \pm 0.10$ & $6.50 \pm 0.10$ & $0.72 \pm 0.01$ & $0.50 \pm 0.01$ \\
\hline
\end{tabular}

$\mathrm{CGW}=$ Clarias gariepinus (Weija), $\mathrm{CNW}=$ Chrysichthys nogrodigitatus (Weija), TZW=Tilapia zilli (Weija) $\mathrm{HNN}=$ Heterotis niloticus (Nsawam), $\mathrm{CON}=$ Channa obscura $($ Nsawam), HON= Hepsetus odoe (Nsawam), $\mathrm{TZN}=$ Tilapia zilli $($ Nsawam), CGN= Clarias gariepinus (Nsawam 


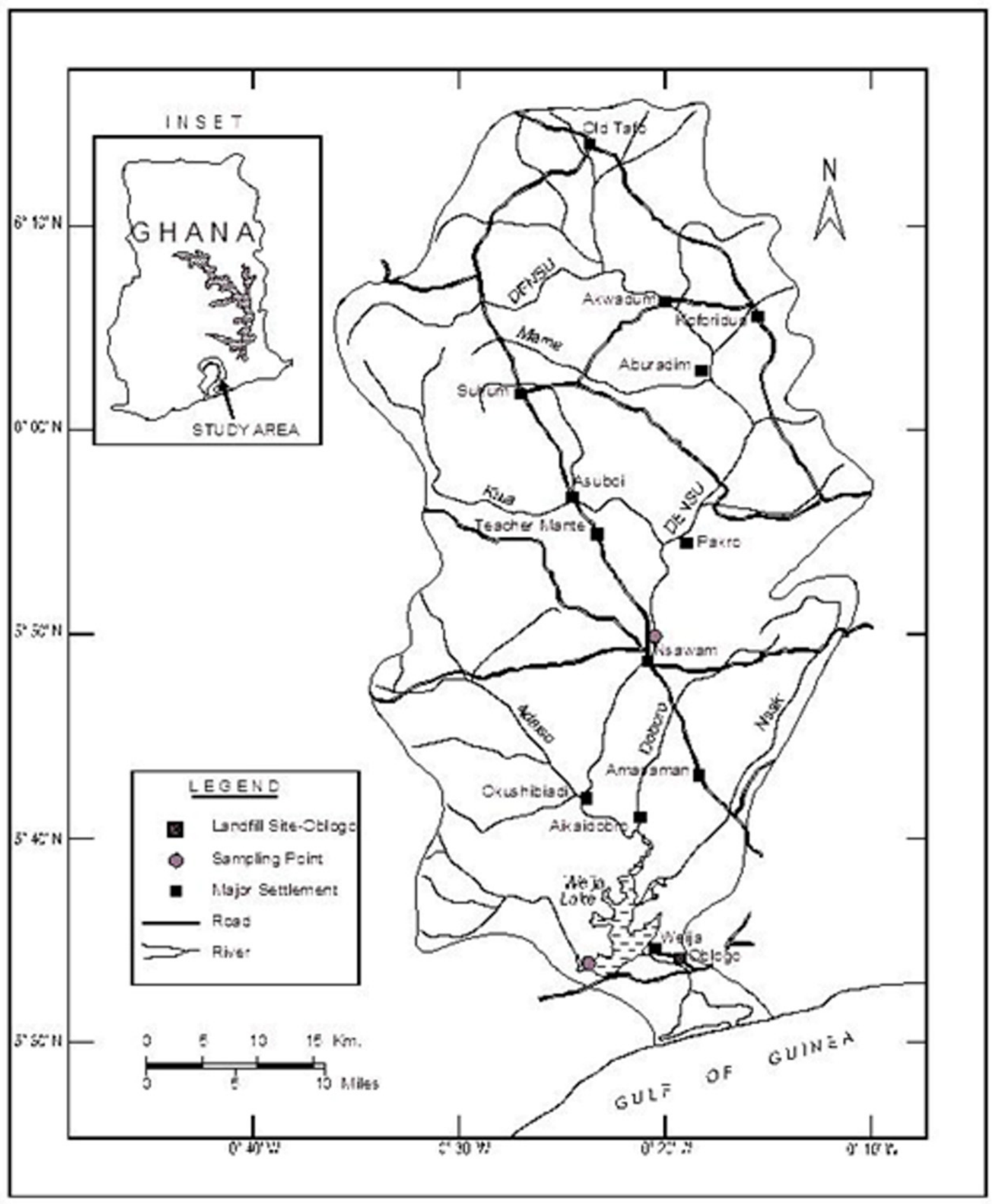

Figure 1. Map of Densu basin showing the sampling points 


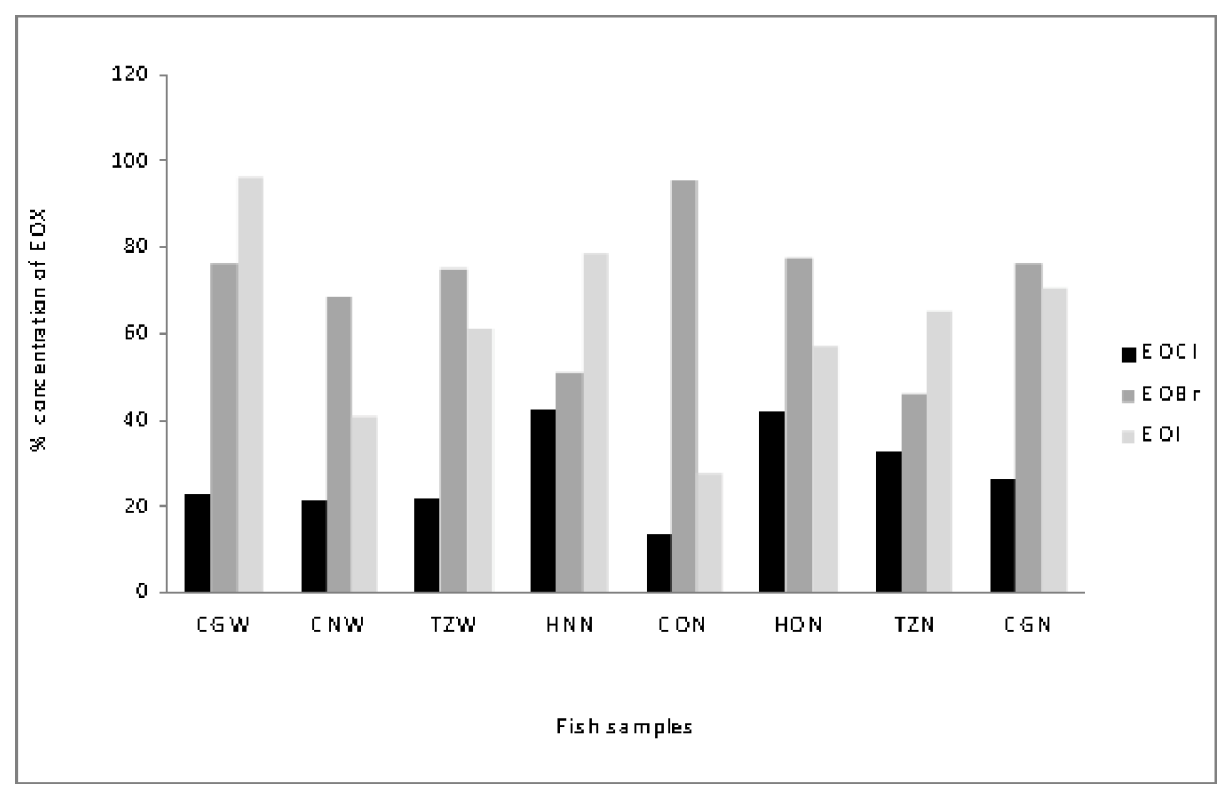

Figure 2. Percentage composition of extractable organohalogen in total halogen

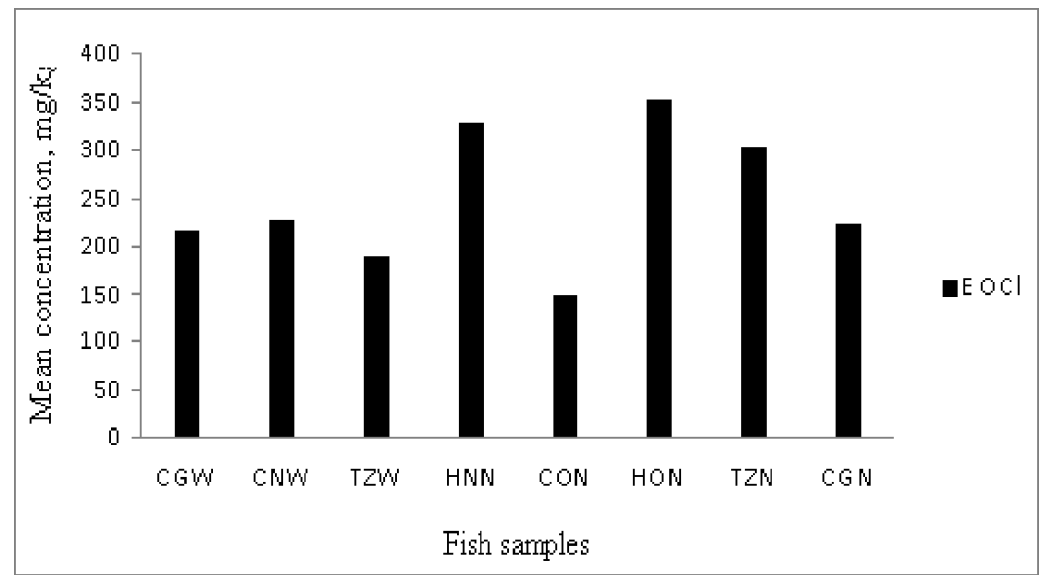

Figure 3. Distribution of $\mathrm{EOCl}$ in the fish samples

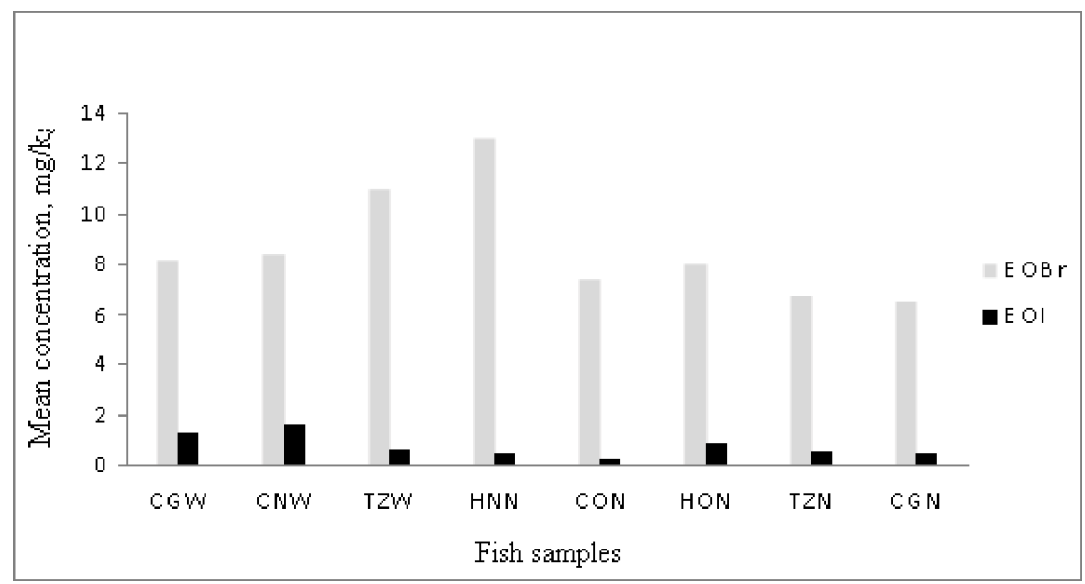

Figure 4. Mean concentrations of EOBr and EOI in the fish samples 